Review

\title{
Production Systems and Prospects of Cowpea (Vigna unguiculata (L.) Walp.) in the United States
}

\author{
O. Adewale Osipitan ${ }^{1,+}+\mathbb{D}$, Jeneen S. Fields ${ }^{2}$, Sassoum Lo ${ }^{1}$ and Ivan Cuvaca ${ }^{3, *}$ \\ 1 Department of Plant Sciences, University of California Davis, Davis, CA 95616, USA; \\ waleos08@yahoo.com (O.A.O.); ssslo@ucdavis.edu (S.L.) \\ 2 Department of Botany and Plant Pathology, Purdue University, West Lafayette, IN 47907, USA; \\ jeneenfields@purdue.edu \\ 3 Division of Plant Sciences, University of Missouri, Columbia, MO 65201, USA \\ * Correspondence: cuvacai@missouri.edu \\ + Currently: Stine Research Center, FMC Corp., Newark, DE 19711, USA.
}

Citation: Osipitan, O.A.; Fields, J.S.; Lo, S.; Cuvaca, I. Production Systems and Prospects of Cowpea (Vigna unguiculata (L.) Walp.) in the United States. Agronomy 2021, 11, 2312. https://doi.org/10.3390/agronomy 11112312

Academic Editor: Pavlos Tsouvaltzis

Received: 12 September 2021

Accepted: 12 November 2021

Published: 16 November 2021

Publisher's Note: MDPI stays neutral with regard to jurisdictional claims in published maps and institutional affiliations.

Copyright: (c) 2021 by the authors. Licensee MDPI, Basel, Switzerland. This article is an open access article distributed under the terms and conditions of the Creative Commons Attribution (CC BY) license (https:// creativecommons.org/licenses/by/ $4.0 /)$.
Abstract: Cowpea (Vigna unguiculata (L.) Walp.) is an important legume crop with enormous nutritional, agronomic and economic value. Cowpea constitutes a large portion of the daily diet among many people in Africa, Asia, Central America, and Southern America. The United States was among the top 10 global producers of cowpea until 1967, when cowpea was grown primarily for soil management and livestock feed. With the projected increase in the minority population in the United States, from $25 \%$ in 1992 to $47 \%$ in 2050, it is expected that the consumption of cowpea in the nation will increase substantially. In this review, we provide information about cowpea production systems and prospects in the United States.

Keywords: blackeye pea; cowpea; crowder pea; production systems; southern pea; United States

\section{Introduction}

Cowpea (Vigna. unguiculata (L.) Walp.), is the most ancient crop known to man [1]. Carbon dating in Ghana suggests possible cultivation of the crop prior to or between 2500-1500 BC [2-4]. Cowpea is a versatile, vascular, annual, and warm season legume. It belongs to the family Fabaceae, subtribe Phaeseolinae, genus Vigna, and section Catjang. All cultivated cowpeas are grouped under the V. unguiculata subspecies unguiculata. The Fabaceae (flowering plants) family includes peas and many perennial and non-herbaceous (e.g., trees and shrubs) leguminous plants [4].

Cowpea originated in Africa, which, according to the Food and Agriculture Organization Corporate Statistical Database [5], accounts for the majority of the world's production $(96.7 \%)$, with Nigeria being the largest producer ( 3.6 million tons in 2019). The precise location of its center of domestication is still controversial. A previous study reported that southern Africa is where most primitive wild varieties occur [4]. Specifically, wild cowpea has been found to occur with a relatively higher frequency within the territory encompassing Botswana, Eswatini (formerly known as Swaziland), Mozambique, Namibia, South Africa, Zambia, and Zimbabwe [6]. However, based on the oldest archeological evidence in Ghana and the existence of weedy intermediates between wild and domesticated cowpeas, eastern and western Africa have been proposed as the center of domestication [2,3,7]. Benin, Burkina Faso, northwestern Cameroon, Niger, Nigeria, and Togo in West Africa have been considered the centers of maximum diversity for cultivated cowpea $[4,8,9]$. While cowpea was introduced into Europe around 300 BC and Asia (India) around 200 BC, its introduction into South America dates back to the 17th century. In the United States (US), cowpea was first introduced into the south in the 18th century. Like in the Caribbean, cowpea's introduction into the Americas was possibly through the "Columbian Exchange" [3,4]. 


\section{Cowpea in the United States}

In the US, cowpea has various names, including blackeye pea, southern pea, pinkeye pea, and crowder pea $[10,11]$. According to FAO, the US harvested 11,750 tons of cowpea cultivated on 5220 ha in 2019 [5]. The major cowpea producing areas in the US include California and several midwestern and southern states (Figure 1). In the US, cowpea is grown for animal fodder and as a vegetable or grain crop, often in rotation with crops such as cotton $[12,13]$. Cowpea seed is sold as either dry or as fresh beans, with the former being the most predominant [12]. Cowpea dry seeds form an important part of the southern US diet, being a staple ingredient for soul food, a fusion of West Africa, Western Europe, and American cuisine [12]. While the majority of cowpea grown in the southeast is processed and sold as fresh-shell peas, much of the commercial crop is sold as dry beans in other states, such as Texas and California. Some of the most common early varieties of cowpea in the US include Elite AR, BVR, MN13, MN150, CB3, CB5, CB46, and CB27 [12,14,15]. On the other hand, Pink Eye Purple Hull, Coloss, Calhaun Purple Hull, 82E9, MN1, MN7, and MN9 are among the most common late varieties [14].

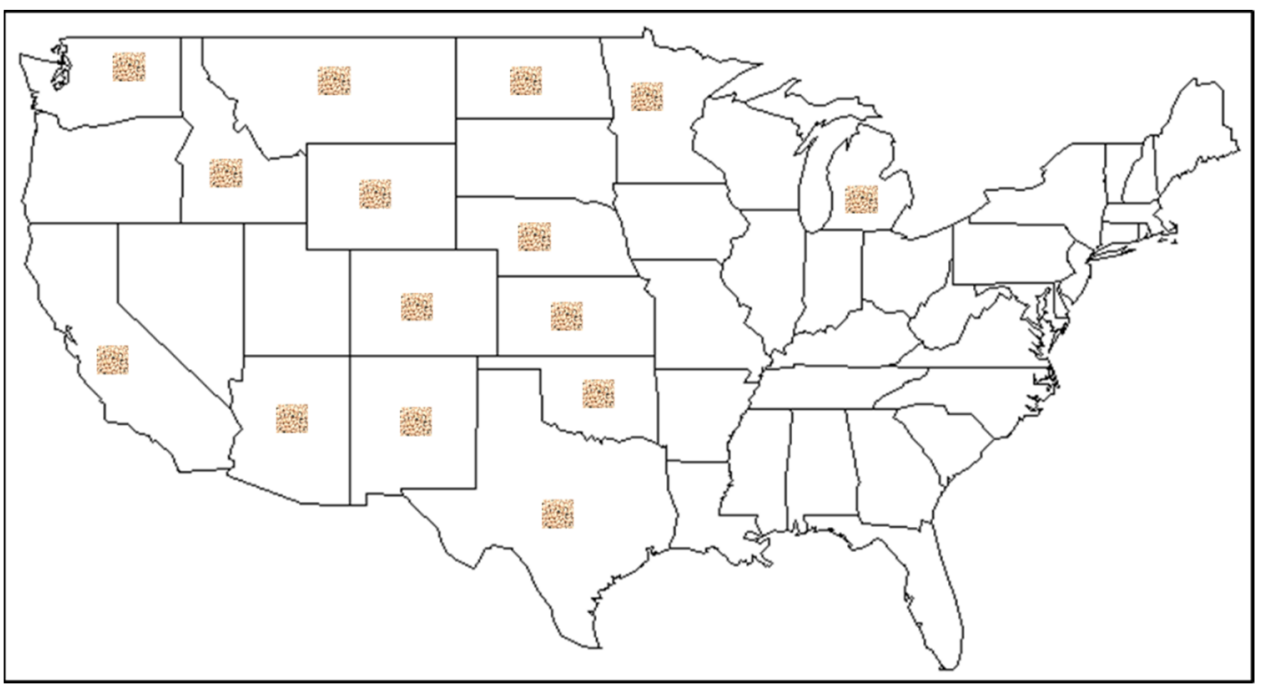

Figure 1. Major bean-producing states in the United States. Information was collected from the United States Dry Beans Commission [16].

\section{Production Systems and Major Challenges in the United States}

Historically, cowpea production in the US has been primarily for soil management and livestock feed. For example, in 1964, 81\% of the 194,000 ha of cowpea were cultivated for soil management and livestock feed, while $19 \%$ were cultivated for seed production [17]. Fery [17] suggested that California, Georgia, and Texas accounted for about $65 \%$ of the production of vegetable (non-fodder) cowpea in the US. Data from the United States Department of Agriculture (USDA) suggest that cowpea was a major agronomic crop in the US, with a peak production area of 2.4 million ha in 1937 (USDA, 1957) thereby placing the US among the top 10 global producers until 1967 (Figures 2 and 3; [5]). Since then, cowpea production area has declined drastically, while the production of other legumes, such as soybean and alfalfa, has increased. FAO estimated the total US acreage to be about 13,233 ha in 2010, compared to 5220 ha in 2019 (Figure 3; [5]). In California, a major cowpea producing state, the acreage of blackeye cowpea was 5341 ha in 2010, compared to 2509 ha in 2019. Nationwide, cowpea seed production was estimated to be 33,503 tons in 1961 compared to 26,535 tons in 2010, and only 11,750 tons in 2019 [5]. The reduction in cowpea acreage and production may be attributed to agronomic challenges that favor the cultivation of optional legumes such as alfalfa, soybeans, etc. According to Fery [17], most of the challenges associated with the decreased production of cowpea in the US could be alleviated by modern agronomic practices and equipment, as well as biotechnology. The lack of mechanized equipment suitable for harvesting is a major challenge facing 
cowpea production. Cowpea is a crop with a sprawling growth habit, thereby necessitating intensive labor for cultivation and harvesting, which increases production costs. Other major challenges include pests, weeds, and diseases, which are discussed in the sub-section below. For example, deficiency in effective insecticides for the control of insect pests such as cowpea curculio (Chalcodermus aeneus) has led to repeated collapses of cowpea production in a southern state, Georgia [18].

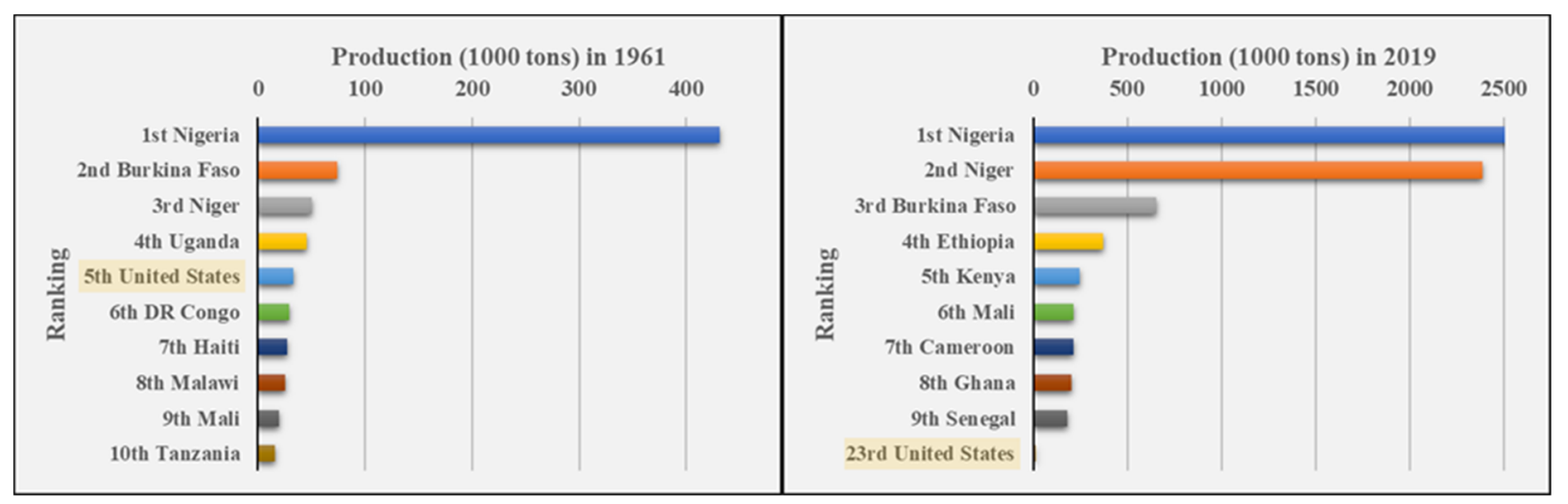

Figure 2. Production ranking of cowpea-producing countries in 1961 and 2019. Note that Nigeria produced 3.6 million tons of cowpea in 2019; data were limited to 2.5 million tons to allow the much lower production of other countries to be reflected in the figure. Data were adapted from Food and Agriculture Organization (FAO) database in August 2021.

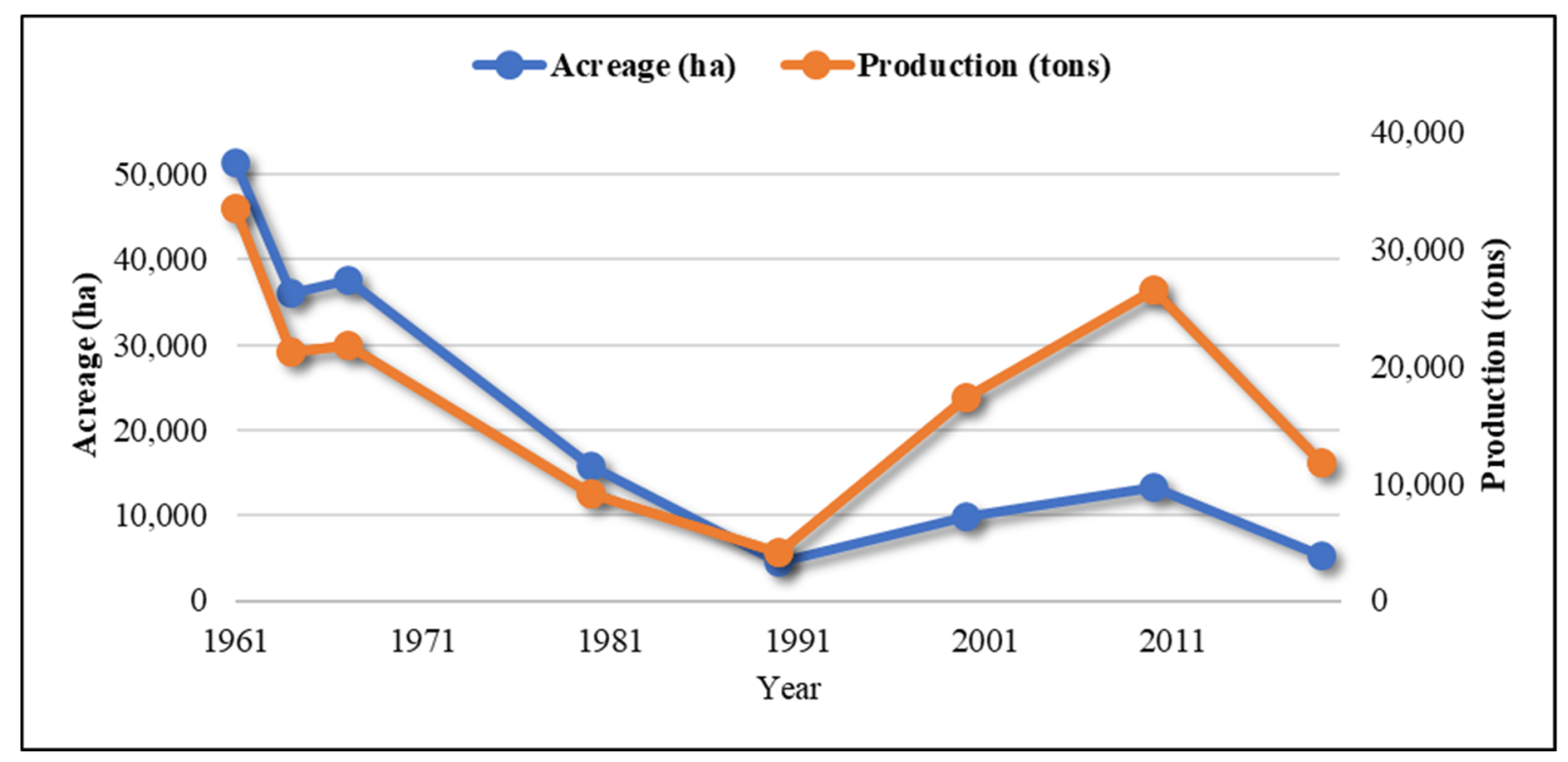

Figure 3. Dry cowpea seed harvested acreage and production in the United States over time. Data were adapted from Food and Agriculture Organization (FAO) database in August 2021.

The economic value of the cowpea industry in the US will be contingent upon the ability to develop innovative inputs and utilize efficient systems that guarantee improved and sustainable productivity. Appropriate and modernized management methods, as well as the selection of high-yielding and disease- and pest-resistant varieties, could also contribute to efficiency.

\subsection{Agronomic Practices}

Cowpea is grown on a wide range of soil types, from sandy to clay loam with moderate amounts of soil water and salinity. The optimum soil $\mathrm{pH}$ ranges from 5.5 to 6.5 . In the US, the early planting season for cowpea begins in late spring, around April, when the soil is 
warm. Germination occurs best when the soil is at least $19{ }^{\circ} \mathrm{C}$ for three days after sowing. Cowpea is mostly grown in single rows of $50 \mathrm{~cm}$ to $100 \mathrm{~cm}$ beds with intra-row spacing of 8 to $10 \mathrm{~cm}$. Spacing can vary based on the available equipment and use of inter-crops. Nitrogen, phosphorus, and potassium fertilizers are rarely required, and if applied, they are usually used in smaller amounts than required for other agronomic crops. A low rate of nitrogen fertilizer may be needed when soil temperature is below $20^{\circ} \mathrm{C}$ to compensate for reduced nodulation and symbiosis.

Cowpea is grown as a rotational crop. For example, in California, cowpea is often grown in rotation with cotton, wheat, corn, alfalfa, sunflower, peanuts, sorghum, and occasionally with melons, Sudangrass, and sweet potato. There are quite a number of cowpea varieties, with each having its limitations. For instance, blackeye pea, a very common cowpea in the US, has eight varieties (CB46, CB3, CB5, CB50, CB27, CB88, CB74, and CB77) available in California (Huynh personal communication). The CB46 was the most grown variety in 1990s despite being small seeded, not growing vigorously and lacking a dense canopy which limits its ability to suppress weeds, particularly when grown in wide rows. CB88 is a good alternative to CB46, as it has larger seeds and grows vigorously. Among all varieties, the newly released CB74 and CB77 have greater yield stability under heat stress and greater resistance to aphids and the lygus bug.

\subsection{Pests and Diseases}

Like every other agronomic crop, pests and diseases are a major challenge facing cowpea production. Utilizing a combination of resistant varieties with pesticides and crop rotation is important to mitigate pest and disease infestation. The most important insect pests in the US include the lygus bug (Lygus hesparus and Lygus elisus), cowpea curculio (Chalcodermus aeneus), cowpea aphid (Aphis craccivora), European corn borer (Elasmophalpus lignosellus), corn earworm (Heliothis zea), foliage thrips (Frankliniella spp.), cowpea weevil (Callosobruchus maculatus), serpentine leaf miner (Liriomyza spp.), and southern green stink bug (Nezara viridula). Some cowpea varieties have been developed with resistance to curculio, stink bugs, and weevils [17].

Root-knot nematodes (RKN) are major pests interfering with cowpea production in the US. They cause substantial damage to the cowpea plant root system and reduce yield by interfering with the uptake of water and nutrients and translocation of assimilates [18]. The most common among these pests include the Javanese (Meloidogyne Javanica), southern (Meloidogyne incognita), northern (Meloidogyne hepla), and peanut (Meloidogyne arenaria) root-knot nematode. Several commercial cultivars of cowpea with resistance to these RKN species have been developed. However, some populations of the nematodes are $R K$-virulent, meaning that the narrow-based genetic resistance conferred by the $R K$ genes are not effective against those populations [19]. A novel RKN resistance QTL has been identified by researchers at the University of California-Riverside. The presence of this QTL is expected to broaden resistance to RKN. Because of the high costs of nematicides, the use of nematicides in cowpea may not be cost effective and practical. However, cowpea can benefit from residual effects if the preceding crop with a higher cash value is treated with a nematicide [15].

In general, cowpeas are typically susceptible to various diseases. These diseases tend to proliferate when soil is excessively moist, and the temperature is cooler. The most common cowpea diseases in the US are bacterial canker (Xanthomonas vignicola), charcoal rot (Macrophomina phaseolina), Rhizoctonia root rot (Rhizoctonia solani), southern blight (Sclerotium rolfsii), Cercospora leaf spot (Cercospora cruenta), Fusarium wilt (Fusarium oxysporum), and Fusarium root rot (Fusarium solani). Viral diseases are among the most prevalent diseases in the southern US particularly during fall cultivation; however, they tend to be less problematic in California. Some of the most common viruses are blackeye bean cowpea mosaic virus (BICMV), southern bean mosaic virus (SBMV), cucumber mosaic virus (CMV), cowpea chlorotic mottle virus (CCMV), cowpea severe mosaic virus (CSV), and peanut stunt virus (PSV). Different tactics are used to control insect pests and diseases 
in cowpea. However, it is recommended that integrated approaches with targeted control be used to break the cycle of both pests and diseases. Previous studies have shown that an integrated approach that involved planting pathogen-free and resistant cowpea seeds early in the season, in combination with crop rotation and pesticide usage, could break the cycle of diseases and prevent their establishment [15].

\subsection{Weed Management Challenges}

Weeds are among the most problematic pests in cowpea production. A season-long weed interference in cowpea can cause up to $76 \%$ yield loss, as weeds are outstanding competitors for water, nutrient, and light, particularly at the early critical cowpea growth stage [20]. Studies have shown that weed interference is most critical during the first 14 to 40 days of cowpea growth. This period allows cowpea to grow and close the canopy, which provides self-protection against late emerging weeds. However, the critical period might vary with the prevailing environmental conditions, level of weed infestations, composition of the weed population, pre-crop emergence management practices, soil moisture, fertility level, cowpea cultivar, and plant density [21,22].

Weeds such as nightshades (Solanum spp.), pigweeds (Amaranth spp.), foxtails (Setaria spp.), groundcherries (Physalis spp.), cocklebur (Xanthium strumarium), velvetleaf (Abutilon theophrasti), and common ragweed (Ambrosia artemisiifolia) have been found in cowpea fields in California and southern states [15]. In addition to causing yield losses, weeds can reduce the quality of cowpea seeds with contamination. Weeds can also interfere with harvesting, delay the drying of cowpea seeds, and make threshing difficult. Cultural and chemical approaches are often employed to control weeds in cowpea in the US. Cultural methods include those farmers employ to give the crop an advantage over weeds. Some examples include the adjustment of row spacing and plant density, crop rotation, water management (mulch planting), and cultivation. The former two have been discussed in a previous research on soybean [23]. The success of crop rotation for weed control is based on the use of crop sequences that create fluctuating patterns of resource competition, microsite disturbance, allelopathic interference, and chemical and mechanical damage to cause a wobbly and inhospitable environment for weeds [24,25]. For example, an infestation of pigweed and black nightshade can be substantially reduced in cowpea by employing a crop rotation system that involves winter cereals [26]. This method allows easy control of the weeds with a wide range of options. Another commonly used cultural method is mulch planting. This involves planting cowpea seeds in a moist, deep soil layer and leaving dry mulch on the soil surface. Because of the relatively large seed size of cowpea, it can emerge through the dry-surface mulch with ease, compared to weed seeds, which are usually smaller. If irrigation is delayed for several days, this method allows cowpea to emerge before most weeds and gives it a competitive advantage. The mulch planting is complemented with the cultivation of the weed seedling that could emerge [15].

Cultural practices are usually supplemented with the preplant or preemergence application of herbicides. Unlike other legumes, such as soybean and alfalfa, there is a limited number of herbicides available for weed control in cowpea farming. This could further explain the decline in cowpea production in the US. The most commonly used preplant incorporated or preemergence herbicides in cowpea in the US are pendimethalin, trifluralin, s-metolachlor, alachlor, and DCPA (Dacthal). Cowpea also has limited postemergence herbicides, most only control grasses. Some examples include clethodim, fuselage, and sethoxydim.

\section{Economic Outlook}

There is limited information on the economic projections for cowpea in the US. Transparency Market Research [27] estimated current global cowpea sales to be over USD 6.3 billion, with an estimated growth of USD 10.5 billion by 2050. Globally, total production was reported to be 8 million tons, with an average yield of 1.4 tons/ha in 2019 [5]. The average seed yield of cowpea varies between countries [5]. In 2019, the 
FAO [5] reported a cowpea seed yield average of 2.25 tons/ha for the US, which was 2.7-, 4.7-, and 5.4-fold higher than those of the world's top three producing countries: Nigeria, Burkina Faso, and Niger, respectively. In general, the FAO data indicate that cowpea production is experiencing a year-to-year increase in productivity per unit area in most countries.

Cowpea is economically valued for its important nutritional contents, such as low fat, high fiber, and high protein content [28]. Efforts have been made in developing improved cowpea varieties. These efforts have resulted in a documented increase in seed protein content. For example, in the 1990s, several varieties of cultivated cowpea were reported to have a protein content ranging between 20-30\% [28]. More recently, Dakora and Belane [29] identified several cowpea genotypes with a higher protein content, up to $40 \%$. A study by Weng et al. [30] showed that a cowpea accession collected from Florida had the highest seed protein $(28.9 \%)$ among the evaluated 173 USDA accessions.

Amino acids and vitamins are equally important in determining the overall nutritional value of a crop. Cowpea contains 17 of the 20 amino acids, several of which are essential amino acids, such as valine, leucine, phenylalanine, and lysine. Some of these amino acids are key ingredients in animal feed, playing a vital role in poultry and beef production. Cowpea leaves also have a significant economic and nutritional value, providing a reliable source of protein, vitamins (A, C, B1, B2, B5, and B9) and several important minerals that could help subvert food insecurity and malnutrition of over 239 million people globally [31,32].

In general, cowpea consumption is highest in developing countries, where the population growth rates are highest, further increasing the demand for this valuable crop. In developed nations, however, cowpea holds potential as an alternative food because of its nutritional value and nutraceutical benefit. Changes in diet and increased demand for plant-based protein is expected to drive the growth of cowpea market in developed countries such as the US [27]. Recent studies have reported that the protein content of cowpea is comparable to soybean [29]; however, an advantage of cowpea is that it has a higher digestibility and is more drought-tolerant than soybean [33]. In the US, the minority population that traditionally consumes cowpea is projected to grow from $25 \%$ in 1992 to $47 \%$ in 2050 [34]. Therefore, it is expected that the demand for cowpea will increase substantially. In addition, the increasing popularity of cowpea as a healthier alternative to soybean in the US is expected to increase cowpea demand [35].

An additional economic benefit of cowpea is its ability to improve soil fertility through nitrogen fixation and its ability to serve as a biological tool for soil conservation through cover cropping. As mentioned earlier, a large portion of cowpea cultivated in the US is used for soil management [17]. It is also important to note that cowpea has been proposed as a biological tool for weed control through cover cropping [36,37]. This is partly due to its ability to sprawl and provide rapid canopy cover against late emerging weeds, thereby minimizing the economic loss caused by the weeds.

\section{Marketing Systems}

Cowpea can be sold as a dried bean, canned bean, fresh bean, and flour. The bean is often included in soup mixtures and can be found in the frozen section in grocery stores throughout the country. Despite its smaller market share compared with other crops, cowpea is well established in certain markets, such as California. In this area, the seed is primarily sold as dry seed, whereas in certain southern states, both dry and fresh seeds are sold due to a high demand for fresh-shell peas and canning by freezing companies that process the crop.

Cowpea is often sold in produce auctions, farmers markets, and through consumer produce subscriptions. Marketing strategies for cowpea in the US tend to focus on the popular blackeye pea and crowder peas [38]. Key players in the market seem to be based outside of the US. These leaders have focused on producing dry beans for distribution around the world. About 10-30\% of blackeye peas produced in the US are exported to 
other countries, and the volume exported is often determined by the international price. Locally, there is a year-round demand for blackeye cowpea; however, the demand usually peaks during the last four months of the year due to increased packaging for the new year [15].

The price of dry cowpea ranges from USD 0.4 to USD $0.6 / \mathrm{kg}$; canned cowpea ranges from USD 0.5 to USD $1 / \mathrm{kg}$; and fresh cowpea ranges from USD 0.3 to USD $0.5 / \mathrm{kg}$. The price of dry cowpea is comparable to that of soybean. However, it is less profitable to produce cowpea compared to soybean, partly because of its production costs.

\section{Research and Improvement Efforts in the United States}

Progress has been made in the development of cowpea varieties adapted to selected regions in the US. Major breeding programs are housed in South Carolina (USDA), Louisiana (Louisiana State University), California (University of California Riverside), Texas (Texas A\&M University) and Arkansas (University of Arkansas) [12]. While the primary objectives of existing breeding programs are to improve grain yield and quality, efforts have also been made to develop varieties with resistance to insects and diseases, which are major constraints to cowpea production [11,19].

Early research activities on cowpea involved heat tolerance during different developmental stages [39-41], root knot-nematode resistance [42,43], and striga resistance [44,45]. More recently, efforts have been focused on mapping drought-related traits [46-48], thrips resistance [49,50], aphid resistance [51], and seed size [52,53].

Despite the progress in research, cowpea has been lacking essential genetic and genomic resources and investment until recently. Early efforts generated over 250,000 genespace sequence reads, accounting for approximately $160 \mathrm{Mb}$ of the cowpea genome [54], as well as a 1536 single-nucleotide polymorphism (SNPs) Golden Gate assay [55]. Recently, numerous genetic and genomic resources have been developed. Among these are an Illumina genotyping array containing 51,128 SNPs [56], a reference genome [57], an eight-parent multiparent advanced generation intercross (MAGIC) population [58], and a mini-core population representing worldwide diversity of domesticated cowpea [9]. Using these resources, major quantitative trait loci (QTL), and candidate genes for various traits have been reported. These include domestication-related traits [59-61], key agronomics traits $[9,58,62]$, seed coat traits $[63,64]$, and biotic stress traits $[19,65]$. These studies present major advances in cowpea research, including exploring the genetic diversity of domesticated cowpea [9].

Others have also explored the genetic diversity of cowpea using a diverse set of 768 cultivated accessions from the USDA Germplasm Resources Information Network (GRIN) cowpea collection [66]. These resources have enabled progress in cowpea genetics and provide great opportunities for future improvement efforts. Furthermore, increasing the precision of phenotyping approaches along with genomic selection, speed breeding, and genome editing tools will accelerate improvement efforts. Key areas of improvement include insect pest and disease resistance, heat and drought tolerance, and seed quality, among other traits. These efforts will be essential to increase the production of cowpea as a globally important source of nutrition.

\section{Conclusions}

Cowpea holds enormous potential to expand its market share in the US. Its popularity as an alternative food for a healthier diet has increased its demand for use as a plantbased protein. Cowpea offers an alternative crop for farmers who grow protein for animal and human consumption. Farmers can effectively compete in the export market to help with global demand for cowpea as well provide an adequate supply for the U.S. The projected rise in the minority population in the US will also likely increase cowpea demand. Considerable progress has been made in cowpea research and breeding, but much remains to be done. Support of cowpea research will assure the development and maximization of this useful legume for both human and animal benefits. The recent availability of more 
genetic and genomic resources has enabled the identification of QTLs with more precision and candidate genes for important agronomic traits. With over 700 entries in the GRIN plant germplasm database in the US, more than 15,000 accessions available through the International Institute of Tropical Agriculture (IITA) and even more available globally, cowpea's genetic diversity and potential could be further explored to meet the needs of a market that is expected to grow.

Author Contributions: All authors contributed to the review of available literature, drafting, and editing the manuscript. All authors have read and agreed to the published version of the manuscript.

Funding: This work received no external funding.

Institutional Review Board Statement: Not applicable.

Informed Consent Statement: Not applicable.

Data Availability Statement: Not applicable.

Acknowledgments: We thank all anonymous reviewers of this manuscript.

Conflicts of Interest: The authors declare no conflict of interest.

\section{References}

1. Kalloo, G.; Bergh, B. Genetic Improvement of Vegetable Crops; Newnes: Oxford, UK, 2012.

2. D'Andrea, A.C.; Kahlheber, S.; Logan, A.L.; Watson, D.J. Early domesticated cowpea (Vigna unguiculata) from Central Ghana. Antiquity 2007, 81, 686-698. [CrossRef]

3. Herniter, I.A.; Muñoz-Amatriaín, M.; Close, T.J. Genetic, textual, and archeological evidence of the historical global spread of cowpea (Vigna unguiculata [L.] Walp.). Legume Sci. 2020, 2, e57. [CrossRef]

4. $\quad$ Singh, B. Advances in Cowpea Research; IITA: Ibadan, Nigeria, 1997.

5. FAOSTAT Database. 2021. Available online: http://www.fao.org/faostat (accessed on 15 August 2021).

6. Padulosi, S.; Ng, N. Origin, taxonomy, and morphology of Vigna unguiculata (L.) Walp. In Advances in Cowpea Research; IITA: Ibadan, Nigeria, 1997; pp. 1-12.

7. Vaillancourt, R.; Weeden, N. Chloroplast DNA polymorphism suggests Nigerian center of domestication for the cowpea, Vigna unguiculata (Leguminosae). Am. J. Bot. 1992, 79, 1194-1199. [CrossRef] [PubMed]

8. Fatokun, C.; Girma, G.; Abberton, M.; Gedil, M.; Unachukwu, N.; Oyatomi, O.; Yusuf, M.; Rabbi, I.; Boukar, O. Genetic diversity and population structure of a mini-core subset from the world cowpea (Vigna unguiculata (L.) Walp.) germplasm collection. Sci. Rep. 2018, 8, 16035. [CrossRef]

9. Munoz-Amatriain, M.; Lo, S.; Herniter, I.A.; Boukar, O.; Fatokun, C.; Carvalho, M.; Castro, I.; Guo, Y.-N.; Huynh, B.-L.; Roberts, P.A. The UCR Minicore: A valuable resource for cowpea research and breeding. Legume Sci. 2021, 3, e95. [CrossRef]

10. Gómez, C. Cowpea: Post-Harvest Operations; FAO of United Nations: Rome, Italy, 2004.

11. Timko, M.P.; Ehlers, J.D.; Roberts, P.A. Cowpea. In Pulses, Sugar and Tuber Crops; Springer: Berlin/Heidelberg, Germany, 2007; pp. $49-67$.

12. Fery, R.; Halli, A. Cowpea breeding in the USA: New varieties and improved germplasm. Chall. Oppor. Enhancing Sustain. Cowpea Prod. 2002, 62, 424-428.

13. Wight, W.F. The History of the Cowpea and Its Introduction into America; US Government Printing Office: Washington, DC, USA, 1907.

14. Davis, D.; Oelke, E.; Oplinger, E.; Doll, J.; Hanson, C.; Putnam, D. Cowpea. In Alternative Field Crops Manual; University of Wisconsin Cooperative or Extension Service: Madison, WI, USA, 1991. Available online: http://www.hort.purdue.edu/newcrop/ afcm/cowpea.Html (accessed on 15 August 2021).

15. Hall, A.E.; Frate, C.A. Blackeye Bean Production in California; University of California, Agriculture and Natural Resources: Davis, CA, USA, 1996; Volume 21518.

16. U.S. Dry Bean Commission. Dry Bean Production across the US. 2014. Available online: www.usdrybeans.com (accessed on 15 August 2021).

17. Fery, R.L. The cowpea: Production, utilization, and research in the United States. Hortic. Rev. 1990, 12, $197-222$.

18. Riley, D.G.; Sparks, A.N. Chalcodermus aeneus (Coleoptera: Curculionidae): Historical pest status, potential for spread, and current management. Fla. Entomol. 2019, 102, 490-494. [CrossRef]

19. Ndeve, A.D.; Santos, J.R.; Matthews, W.C.; Huynh, B.L.; Guo, Y.-N.; Lo, S.; Muñoz-Amatriaín, M.; Roberts, P.A. A novel root-knot nematode resistance QTL on chromosome Vu01 in Cowpea. G3 Genes Genomes Genet. 2019, 9, 1199-1209. [CrossRef]

20. Osipitan, O.A. Weed interference and control in cowpea production: A review. J. Agric. Sci. 2017, 9, 11-20.

21. Norsworthy, J.K.; Oliveira, M.J. Comparison of the critical period for weed control in wide-and narrow-row corn. Weed Sci. 2004, 52, 802-807. [CrossRef] 
22. Osipitan, O.A.; Adigun, J.A.; Kolawole, R.O. Row spacing determines critical period of weed control in crop: Cowpea (Vigna unguiculata) as a case study. Azarian J. Agric. 2016, 3, 90-96.

23. Daramola, O.S.; Adeyemi, O.R.; Adigun, J.A.; Adejuyigbe, C.O. Influence of row spacing and weed control methods on weed population dynamics in soybean (Glycine max L.). Int. J. Pest Manag. 2020, 66, 1-16. [CrossRef]

24. Adigun, J.; Osipitan, A.; Lagoke, S.T.; Adeyemi, R.O.; Afolami, S.O. Growth and yield performance of cowpea (Vigna unguiculata (L.) Walp) as influenced by row-spacing and period of weed interference in South-West Nigeria. J. Agric. Sci. 2014, 6, 188. [CrossRef]

25. Liebman, M.; Dyck, E. Crop rotation and intercropping strategies for weed management. Ecol. Appl. 1993, 3, 92-122. [CrossRef] [PubMed]

26. Ehlers, J.; Hall, A. Cowpea (Vigna unguiculata L. Walp). Field Crop. Res. 1997, 53, 187-204. [CrossRef]

27. Transparency Market Research (2020) Cowpea Market: Cowpeas Market (Nature: Organic and Conventional; Form: Whole, Flour, and Split; and End-use Application: B2B, Household/Retail, Store-based Retail, and Online [e-Commerce])-Global Industry Analysis, Size, Share, Growth, Trends, and Forecast, 2020-2030. Available online: https:/ /www.transparencymarketresearch com/cowpeas-market.html (accessed on 13 November 2021).

28. Hussain, M.; Basahy, A. Nutrient composition and ammo acid pattern of cowpea (Vigna unguiculata (L.) Walp, Fabaceae) grown in the Gizan area of Saudi Arabia. Int. J. Food Sci. Nutr. 1998, 49, 117-124. [CrossRef]

29. Dakora, F.D.; Belane, A.K. Evaluation of protein and micronutrient levels in edible cowpea (Vigna Unguiculata L. Walp.) leaves and seeds. Front. Sustain. Food Syst. 2019, 3, 70. [CrossRef]

30. Weng, Y.; Qin, J.; Eaton, S.; Yang, Y.; Ravelombola, W.S.; Shi, A. Evaluation of seed protein content in USDA cowpea germplasm. HortScience 2019, 54, 814-817. [CrossRef]

31. Fanzo, J. The Nutrition Challenge in Sub-Saharan Africa; United Nations Development Programme: New York, NY, USA; Regional Bureau for Africa: New York, NY, USA, 2012.

32. Gerrano, A.S.; Jansen van Rensburg, W.S.; Venter, S.L.; Shargie, N.G.; Amelework, B.A.; Shimelis, H.A.; Labuschagne, M.T. Selection of cowpea genotypes based on grain mineral and total protein content. Acta Agric. Scand. Sect. B—Soil Plant. Sci. 2019, 69, 155-166. [CrossRef]

33. Quinn, J.; Myers, R. Cowpea: A Versatile Legume for Hot, Dry Conditions; Thomas Jefferson Institute: Portland, OR, USA, 1999. Available online: www.hort.purdue.edu/newcroparticles/ji-compeahtml (accessed on 13 November 2021).

34. Day, J.C. Population Projections of the United States, by Age, Sex, Race, and Hispanic Origin: 1992 to 2050; US Department of Commerce: Washington, DC, USA; Economics and Statistics Administration, Bureau of the Census: Sutland, MD, USA, 1992.

35. Bingen, R.J.; Hall, A.; Ndoye, M. California cowpeas and food policy in Senegal. World Dev. 1988, 16, 857-865. [CrossRef]

36. Osipitan, O.A.; Dille, J.A.; Assefa, Y.; Radicetti, E.; Ayeni, A.; Knezevic, S.Z. Impact of cover crop management on level of weed suppression: A meta-analysis. Crop. Sci. 2019, 59, 833-842. [CrossRef]

37. Soti, P.; Racelis, A. Cover crops for weed suppression in organic vegetable systems in semiarid subtropical Texas. Org. Agric. 2020, 10, 429-436. [CrossRef]

38. Kaiser, C.; Ernst, M. Cowpea (Southernpea). In CCD-CP-119; Center for Crop Diversification: Lexington, KY, USA; University of Kentucky College of Agriculture, Food and Environment: Lexington, KY, USA, 2021. Available online: http:/ / www.uky.edu/ ccd/sites/www.uky.edu.ccd/files/cowpea.pdf (accessed on 13 November 2021).

39. Ahmed, F.E.; Hall, A.E. Heat injury during early floral bud development in cowpea. Crop. Sci. 1993, 33, 764-767. [CrossRef]

40. Ahmed, F.E.; Hall, A.E.; DeMason, D.A. Heat injury during floral development in cowpea (Vigna unguiculata, Fabaceae). Am. J. Bot. 1992, 79, 784-791. [CrossRef]

41. Ismail, A.M.; Hall, A.E. Reproductive-stage heat tolerance, leaf membrane thermostability and plant morphology in cowpea. Crop. Sci. 1999, 39, 1762-1768. [CrossRef]

42. Ehlers, J.; Matthews, W., Jr.; Hall, A.; Roberts, P. Inheritance of a broad-based form of root-knot nematode resistance in cowpea. Crop. Sci. 2000, 40, 611-618. [CrossRef]

43. Roberts, P.; Matthews, W.; Ehlers, J. New resistance to virulent root-knot nematodes linked to the Rk locus of cowpea. Crop. Sci. 1996, 36, 889-894. [CrossRef]

44. Li, J.; Timko, M.P. Gene-for-gene resistance in Striga-cowpea associations. Science 2009, 325, 1094. [CrossRef]

45. Ouédraogo, J.; Maheshwari, V.; Berner, D.; St-Pierre, C.-A.; Belzile, F.; Timko, M. Identification of AFLP markers linked to resistance of cowpea (Vigna unguiculata L.) to parasitism by Striga gesnerioides. Theor. Appl. Genet. 2001, 102, 1029-1036. [CrossRef]

46. Muchero, W.; Ehlers, J.D.; Close, T.J.; Roberts, P.A. Mapping QTL for drought stress-induced premature senescence and maturity in cowpea [Vigna unguiculata (L.) Walp.]. Tag. Theor. Appl. Genet. 2009, 118, 849-863. [CrossRef] [PubMed]

47. Muchero, W.; Ehlers, J.D.; Roberts, P.A. Restriction site polymorphism-based candidate gene mapping for seedling drought tolerance in cowpea [Vigna unguiculata (L.) Walp.]. Tag. Theor. Appl. Genet. 2010, 120, 509-518. [CrossRef] [PubMed]

48. Muchero, W.; Roberts, P.A.; Diop, N.N.; Drabo, I.; Cisse, N.; Close, T.J.; Muranaka, S.; Boukar, O.; Ehlers, J.D. Genetic architecture of delayed senescence, biomass, and grain yield under drought stress in cowpea. PLoS ONE 2013, 8, e70041. [CrossRef] [PubMed]

49. Lucas, M.R.; Ehlers, J.D.; Roberts, P.A.; Close, T.J. Markers for quantitative inheritance of resistance to foliar thrips in cowpea. Crop. Sci. 2012, 52, 2075-2081. [CrossRef]

50. Muchero, W.; Ehlers, J.D.; Roberts, P.A. QTL analysis for resistance to foliar damage caused by Thrips tabaci and Frankliniella schultzei (Thysanoptera: Thripidae) feeding in cowpea [Vigna unguiculata (L.) Walp.]. Mol. Breed. 2010, 25, 47-56. [CrossRef] 
51. Huynh, B.-L.; Ehlers, J.D.; Ndeve, A.; Wanamaker, S.; Lucas, M.R.; Close, T.J.; Roberts, P.A. Genetic mapping and legume synteny of aphid resistance in African cowpea (Vigna unguiculata L. Walp.) grown in California. Mol. Breed. 2015, 35, 1-9. [CrossRef]

52. Lucas, M.R.; Huynh, B.L.; da Silva Vinholes, P.; Cisse, N.; Drabo, I.; Ehlers, J.D.; Roberts, P.A.; Close, T.J. Association Studies and Legume Synteny Reveal Haplotypes Determining Seed Size in Vigna unguiculata. Front. Plant Sci. 2013, 4, 95. [CrossRef]

53. Lucas, M.R.; Huynh, B.L.; Roberts, P.A.; Close, T.J. Introgression of a rare haplotype from Southeastern Africa to breed California blackeyes with larger seeds. Front. Plant Sci. 2015, 6, 126. [CrossRef]

54. Timko, M.P.; Rushton, P.J.; Laudeman, T.W.; Bokowiec, M.T.; Chipumuro, E.; Cheung, F.; Town, C.D.; Chen, X. Sequencing and analysis of the gene-rich space of cowpea. BMC Genom. 2008, 9, 103. [CrossRef]

55. Muchero, W.; Diop, N.N.; Bhat, P.R.; Fenton, R.D.; Wanamaker, S.; Pottorff, M.; Hearne, S.; Cisse, N.; Fatokun, C.; Ehlers, J.D.; et al. A consensus genetic map of cowpea [Vigna unguiculata (L) Walp.] and synteny based on EST-derived SNPs. Proc. Natl. Acad. Sci. USA 2009, 106, 18159-18164. [CrossRef]

56. Muñoz-Amatriaín, M.; Mirebrahim, H.; Xu, P.; Wanamaker, S.I.; Luo, M.; Alhakami, H.; Alpert, M.; Atokple, I.; Batieno, B.J.; Boukar, O. Genome resources for climate-resilient cowpea, an essential crop for food security. Plant J. 2017, 89, 1042-1054 [CrossRef]

57. Lonardi, S.; Muñoz-Amatriaín, M.; Liang, Q.; Shu, S.; Wanamaker, S.I.; Lo, S.; Tanskanen, J.; Schulman, A.H.; Zhu, T.; Luo, M.-C.; et al. The genome of cowpea (Vigna unguiculata [L.] Walp.). Plant J. 2019, 98, 767-782. [CrossRef]

58. Huynh, B.L.; Ehlers, J.D.; Huang, B.E.; Muñoz-Amatriaín, M.; Lonardi, S.; Santos, J.R.; Ndeve, A.; Batieno, B.J.; Boukar, O.; Cisse, N. A multi-parent advanced generation inter-cross (MAGIC) population for genetic analysis and improvement of cowpea (Vigna unguiculata L. Walp.). Plant J. 2018, 93, 1129-1142. [CrossRef]

59. Lo, S.; Fatokun, C.; Boukar, O.; Gepts, P.; Close, T.J.; Muñoz-Amatriaín, M. Identification of QTL for perenniality and floral scent in cowpea (Vigna unguiculata [L.] Walp.). PLoS ONE 2020, 15, e0229167. [CrossRef] [PubMed]

60. Lo, S.; Muñoz-Amatriaín, M.; Boukar, O.; Herniter, I.; Cisse, N.; Guo, Y.-N.; Roberts, P.A.; Xu, S.; Fatokun, C.; Close, T.J. Identification of QTL controlling domestication-related traits in cowpea (Vigna unguiculata L. Walp). Sci. Rep. 2018, 8, 6261. [CrossRef] [PubMed]

61. Lo, S.; Parker, T.; Muñoz-Amatriaín, M.; Berny-Mier y Teran, J.C.; Jernstedt, J.; Close, T.J.; Gepts, P. Genetic, anatomical, and environmental patterns related to pod shattering resistance in domesticated cowpea (Vigna unguiculata [L.] Walp). J. Exp. Bot. 2021, 72, 6219-6229. [CrossRef] [PubMed]

62. Lo, S.; Muñoz-Amatriaín, M.; Hokin, S.A.; Cisse, N.; Roberts, P.A.; Farmer, A.D.; Xu, S.; Close, T.J. A genome-wide association and meta-analysis reveal regions associated with seed size in cowpea [Vigna unguiculata (L.) Walp]. Theor. Appl. Genet. 2019, 132, 3079-3087. [CrossRef] [PubMed]

63. Herniter, I.A.; Lo, R.; Muñoz-Amatriaín, M.; Lo, S.; Guo, Y.-N.; Huynh, B.-L.; Lucas, M.; Jia, Z.; Roberts, P.A.; Lonardi, S.; et al. Seed Coat Pattern QTL and Development in Cowpea (Vigna unguiculata [L.] Walp.). Front. Plant Sci. 2019, 10, 1346. [CrossRef] [PubMed]

64. Herniter, I.A.; Muñoz-Amatriaín, M.; Lo, S.; Guo, Y.-N.; Close, T.J. Identification of Candidate Genes Controlling Black Seed Coat and Pod Tip Color in Cowpea (Vigna unguiculata [L.] Walp). G3: Genes Genomes Genet. 2018, 8, 200521-202018. [CrossRef] [PubMed]

65. Steinbrenner, A.D.; Muñoz-Amatriaín, M.; Chaparro, A.F.; Aguilar-Venegas, J.M.; Lo, S.; Okuda, S.; Glauser, G.; Dongiovanni, J.; Shi, D.; Hall, M. A receptor-like protein mediates plant immune responses to herbivore-associated molecular patterns. Proc. Natl. Acad. Sci. USA 2020, 117, 31510-31518. [CrossRef]

66. Xiong, H.; Shi, A.; Mou, B.; Qin, J.; Motes, D.; Lu, W.; Ma, J.; Weng, Y.; Yang, W.; Wu, D. Genetic diversity and population structure of cowpea (Vigna unguiculata L. Walp). PLoS ONE 2016, 11, e0160941. [CrossRef] [PubMed] 